\title{
A vallásfüggőség mint egy lehetséges új viselkedési addikció vizsgálata serdülőkorú populációban
}

\author{
Kovács Eszter dr. ${ }^{1}$ - Pikó Bettina dr. ${ }^{2}$ \\ ${ }^{1}$ Semmelweis Egyetem, Egészségügyi Menedzserképző Központ, Budapest \\ ${ }^{2}$ Szegedi Tudományegyetem, Általános Orvostudományi Kar, Magatartástudományi Intézet, Szeged
}

\begin{abstract}
Bevezetés: A vallásfüggőség újfajta függőség a viselkedési addikciók sorában, ami a vallásgyakorlás patológiássá válását jelenti. Célkitüzés: A szerzők választ kerestek az alábbi kérdésekre: A vallásfüggőség megjelenik-e serdülőkorban, együtt járhat-e más addikciókkal, illetve hogyan hat az egyén pszichés jóllétére? Módszer: A vallási addikcióra egy rövid szürő kérdő́ivet vettek fel serdülők ( $\mathrm{N}=656$; átlagéletkor = 16,5 év; 49,2\%-uk lány) körében. A szerhasználat (havi és életprevalencia) mellett mérték a pszichés jóllét (például depresszió, agresszió, optimizmus) változóit is. Eredmények: A serdülők körében a vallásosság szintje viszonylag alacsony volt. A minta közel 1\%-a jellemezhető vallásfüggőként, valamint további 16,2\% tartozott a veszélyeztetett szimptomatikus csoportba, míg $83 \%$ tünetmentes volt. A vallásfüggő́k szignifikánsan vallásosabbnak tartják magukat, a vallás szerepét fontosabbnak tartják, többször imádkoznak és járnak templomba. A vallásfüggőség fóként az amfetamin használatával függ össze; alacsonyabb körükben az agresszió szintje, emellett pedig magasabb a vallási jóllét. Következtetések: A vallásosság kiváltképpen bonyolult jelenség, ezért fontos feltárni, hogy a vallásosság mely szintjei funkcionálnak egészségvédő, és melyek egészségkárosító módon. Orv. Hetil., 2015, 156(18), 731-740.
\end{abstract}

Kulcsszavak: vallásosság, addikció, vallásfüggőség, serdülők

\section{Study on religious addiction as a potential novel type of behavioral addiction in an adolescent population}

Introduction: Religious addiction is a new behavioral addiction, featured with pathologic religious activity. Aim: The authors examined whether this new phenomenon appears in adolescence, and whether it correlates with substance use and mental health variables. Method: The General Addiction Screening Tool was used to investigate the presence of religious addiction among youth $(\mathrm{N}=656$; mean age, 16.5 years; $49.2 \%$ females $)$. Besides monthly and lifetime prevalence of substance use, variables of psychological well-being (e.g., depression, aggression, optimism) were also detected. Results: Religiosity was relatively low among adolescents. Nearly $1 \%$ of the sample might be characterized as being addicted to religion, $16.2 \%$ belonged to the symptomatic group, while $83 \%$ of them were asymptomatic. Religious addicts were more likely to be more religious and the role of religion in one's life was more important. Also, they tended to pray and attend the churches more frequently. It was also found that amphetamine use was more frequent among the addicts. In terms of mental health level, aggression scored lower and spiritual well-being reached higher level. Conclusions: Religiosity is a vague phenomenon, and further investigation is needed to detect when healthy enthusiastic religiosity turns into religious addiction.

Keywords: religiosity, addiction, religious addiction, adolescence

Kovács, E., Pikó, B. [Study on religious addiction as a potential novel type of behavioral addiction in an adolescent population]. Orv. Hetil., 2015, 156(18), 731-740.

(Beérkezett: 2015. február 10.; elfogadva: 2015. március 12.) 
A vallásossággal és spiritualitással foglalkozó szakirodalom egyre jelentősebb szerepet kapott az elmúlt évek tudományos életében. Az országos reprezentatív lakossági felmérés, a Hungarostudy arról számolt be, hogy a vallásgyakorlás kedvezőbb egészség-magatartással, a káros szenvedélyek alacsonyabb gyakoriságával és összességében jobb testi és lelki egészséggel jár együtt [1]. A fiatalkori egészség-magatartás tekintetében szintén megerősítést nyert, hogy a vallásosság és vallásgyakorlás - még ha alacsony szintü is - jelentős védelmet jelenthet a serdülő számára a problémaviselkedés tüneteinek kivédésében (például szerkipróbálás, szerfogyasztás, mentális problémák) $[2,3,4]$. Tehát a vallásgyakorlás egészségre gyakorolt sokrétű jótékony hatása ma már epidemiológiailag és klinikailag is igazolást nyert [5].

Ugyanakkor a vallásosság és spiritualitás témaköre nemrég megjelent az addiktológiai szakirodalomban is. $\mathrm{Az}$ addiktológia területén alapvetően a kémiai függőségek kapnak kiemelt szerepet, míg az úgynevezett viselkedési addikciókra sokáig kevesebb figyelem irányult [6]. Annak ellenére, hogy a DSM-V sem kezeli egységes kórképként a viselkedési addikciók széles spektrumát, a szakirodalomban egyre több vizsgálat fokuszál e viselkedési formákra, amelyek közül azonban csak néhány (például a kóros játékszenvedély) szerepel hivatalosan is kórformaként. A viselkedési addikciók közé soroljuk a játékszenvedély-betegséget, a szexuális viselkedés bizonyos anomáliáit, idesorolhatóak a táplálkozási magatartás különböző zavarai (például anorexia és bulimia nervosa), a társfüggőség, a szerelemfüggőség, a munkamánia, a testedzésfüggőség, a vásárlási kényszer, a számítógépes játékoktól való függőség, az internetfüggőség és még sok hasonló viselkedésforma, amelyek száma egyre nő [7]. Alapvetően e viselkedésformák többsége egészséges mértékben jelen lehet az egyén normatív viselkedésében, azonban függőségről vagy problémás viselkedésrôl beszélünk, ha az adott viselkedésforma uralni kezdi a személy viselkedését, a függőség kerül az élet fókuszába, s ennek következtében jelentősen károsítja az egyén életvitelét, illetve a testi és/vagy a lelki egészségét, valamint környezetét, társas kapcsolatait [8]. Amikor az egyén nem képes ellátni a neki szánt társadalmi szerepeket, úgy érzi, hogy az addikció tárgya jelenti életének a középpontját, amelynek a túlzott, kényszeres gyakorlata a kontroll elvesztésével és szociálisan káros következménynyel jár, akkor patológiás viselkedésről van szó [9]. Ilyen értelemben mind a pszichoaktív szerek okozta kémiai addikciók, mind pedig a viselkedési addikciók esetében közös a kényszeresség, a ciklikusság, az ismétlődés és az ártalmak megjelenése [7].

A vallásfüggőség viszonylag nemrégen definiált viselkedési addikció, ami nem tévesztendő össze a vallással összefüggő egyéb patológiás viselkedésformákkal. A szakirodalomban a 2001. szeptember 11-i történések nyomán előtérbe került a vallási fanatizmus számos értelmezési formája, ami a következő angol elnevezések alatt szerepelt: religious pathologies, religious dependence, re- ligious extremism, religious fanaticism, psychoreligious problems $[10,11,12]$. Ezzel kapcsolatban szintén felmerült a kérdés, hogy lehet-e a vallásgyakorlás negatív, sőt egyenesen veszélyes jelenség [13]. Míg azonban a vallási fanatizmus régóta ismert és a társadalomtudományokban is kutatott jelenség, a vallási addikció más szempontok, a viselkedési addikciók fent említett kritériumai alapján értelmezendő viselkedés, amelynek lényege a függőség. Természetesen nem zárható ki átfedés a korábbi fogalmakkal leírt jelenségekkel, azonban viselkedési következményekben el is térhet azoktól.

A szakirodalomban még igen kevés tanulmány foglalkozik ezzel a jelenséggel mind hazai, mind nemzetközi szinten. A diagnosztikus rendszerek nem tartalmazzák, tehát a szó szoros értelmében véve nem betegség, azonban mégis olyan mentális problémának tekinthető, amely kihat az egyén és környezete életére, egészségére [14]. Főként pszichiáterek, pszichológusok és gyakorló pszichoterapeuták számolnak be a kórlefolyás sajátosságairól, amelyek azt igazolják, hogy lényegében abúzusról [15] és következményes függőségről beszélhetünk [16, 17]. Mivel viszonylag új keletú viselkedési addikcióról van szó, definíciója még nem letisztult, a jelenség kevéssé vizsgált terület a nemzetközi kutatásokban, hazánkban pedig, tudomásunk szerint, még egyáltalán nem foglalkozott a témával tudományos kutatás. A fogalom hazai relevanciájának megjelenését viszont az jelzi, hogy helyet kapott a viselkedési addikciókról szóló kötetben (Az addiktológia alapjai IV.), és a viselkedési függőségekre koncentráló tudományos fórumokon is (lásd Magyar Addiktológiai Társaság kongresszusa, illetve a 1st International Conference on Behavioral Addictions) [14, 18, 19].

A vallási addikció egy újfajta függőség a viselkedési addikciók sorában, ami a vallásgyakorlás patológiássá válását, valamint a személy fókuszának beszúkülését jelenti a vallási tevékenységekre. Booth - aki úttörőnek számít a témakörben - a vallásfüggőséget a következőképpen definiálta: „Isten, egy templom vagy egy hitrendszer használata oly módon, hogy a személy elmenekül a valóság elől annak érdekében, hogy növelje önbecsülését vagy fokozza személyes jóllétét” [20]. A vallásfüggőség lényegében diszfunkcionális vallásos hitként fogható fel [21]. Johnson és van Vonderen szerint a vallásfüggöség egyfajta igény a (spirituális) tudatmódosításra, ennyiben tehát hasonló a kémiai addikciókhoz [22]. A vallási addikcióról szóló későbbi tanulmányokban a spiritualitást még inkább beemelik a jelenség meghatározásába; Vanderheyden szerint például a vallási addikció „lélekrombolásként" fogható fel, azaz rombolja a lelki folyamatokat [16]. Taylor emellett a spiritualitás általi megszállottságként értelmezi [23]. Sussman ezt azzal az értelmezéssel egészíti ki, hogy a természetfeletti, transzcendens erőkhöz való erős kötődésről van szó [17]. Mindezt jól öszszegzi a Slobodzien disszertációjában megjelenő átfogó definíció: „A vallásfüggőség egy olyan időszakos és/vagy tartós vallásos és/vagy spirituális mámor, amelyet olyan ismétlődő cselekvés teremt meg, ami patologikus kap- 
csolatot feltételez bármely vallási és/vagy spirituális hangulatmódosító személlyel, szervezettel, hitrendszerrel vagy természetfeletti erővel. Mindezek iránt a vallásfüggő egyén ellenállhatatlan vágyat, szükségletet vagy kényszert érez, miközben fokozza elköteleződését és intenzitását a vallásgyakorlásban, és bizonyítja a klasszikus függőségi tüneteket, például tolerancia vagy megvonás. Ebben a patologikus kapcsolatban gyakran van jelen spirituális és pszichikai függés" [24].

Korábbi tanulmányok szerint a következő személyiségpszichológiai tényezőket fedezhetjük fel vallásfüggők körében: rigiditás (a vallási tanok megkérdőjelezhetetlen elfogadása), a dolgok leegyszerúsített („fekete/fehér” alapú) értékelése, a mágikus-spirituális gondolkodásmód, valamint jellemző még az alacsony önértékelés, a befelé fordulás/izoláció, a magányosság és az elfojtásra való hajlam $[16,23]$. Emellett számos tanulmány említi a pontosság, precizitás és a perfekcionizmus, valamint a neuroticitás, mániás kórképek és kényszeresség faktorait [16, 23, 25]. Más addiktív viselkedésekhez hasonlóan káros hatással van az egyénre és társas kapcsolataira, különösképpen a családi kapcsolatokra vagy a munka világára. A vallásfüggő egyén megpróbál elmenekülni a valóságból, egy egészségtelen-patologikus vallásosságot teremt, amelyben a vallásgyakorlás, a vallásosság uralja a mindennapjait. A vallásfüggő nem képes kilépni a vallásos tartalmak, rítusok és gyakorlatok folyamatos tervezgetéséból, így létrehoz egyfajta állapotot, amelyben képtelen ennek megállítására vagy visszaszorítására. A folyamat során a vallásfüggő képes pszichés, olykor pedig pszichoszomatikus tünetek generálására is, mindezt pedig a belátás hiánya mellett [20, 21, 23, 24, 25].

A vallásfüggőség kialakulása folyamat, amely több szakaszra bontható [20]. A vallási addikciót kezdeti szakaszában nagyon nehéz felismerni. A vallásfüggőnél elsősorban gyors hangulatváltozások, hangulati ingadozások jelentkeznek, amelynek hátterében számos tényező állhat. Az első szakaszban egy viszonylag „kiegyensúlyozott” helyzettel állunk szemben. Excesszív vallásgyakorlás - templomba járás és a Szentírás olvasása - jellemző, amikor a személy önmaga megnyugtatása, az értéktelenség érzésének csökkentése céljából fokuszál a vallási tartalmakra. A vallásgyakorlás egyre intenzívebbé válik, és az egyén hanyagolni kezdi a társas kapcsolatait, valamint társadalmi szerepeinek teljesítése nehézkessé válik. A valahová tartozás élményét, az el- és befogadottság érzését a vallási közösség adja meg. A második szakaszban az intrinszik vallásosság kerül a középpontba, túlzott templomba járás és imádkozás figyelhető meg. Jellemző továbbá az anyagi gondok megjelenése a sok adomány miatt, és a búntudat az esetlegesen kihagyott ima vagy mise esetén. A kényszeresség szintje emelkedik. Az egyén agressziót és konfliktusokat él meg családjában, munkahelyén, baráti körében, így elszigetelődik környezetétől. A vallásban talál egyedül megnyugvást, a problémamegoldásban csak a vallásban talál fogódzókat. A harmadik szakaszban a kontrollvesztés mellett az egyéniség és a self dezintegrálttá válik. A szociális kapcsolatokban nagymértékü hanyatlás következik be, az izoláció egyre nagyobb mértékúvé válik. Az egyén mentálisan és lelkileg kimerül, majd súlyos stresszt és pszichoszomatikus tüneteket is produkál. A vallási eszmék így deviánssá és szélsőségessé válnak.

Láthatjuk tehát, hogy ez a kórforma veszélyes lehet az egyén és a társas közege szempontjából. Különösen serdülőkorban érdemes figyelmet szentelni ennek a jelenségnek, ugyanis a különböző vallási csoportok, új vallási mozgalmak, szekták tagjaikat sok esetben a labilis és bizonytalan identitású, valamint a lelki zavarokkal küszködő személyek közül választják [26]. Nem véletlen, hogy fejlődéstani alapokból kiindulva éppen a serdülők a legfogékonyabbak a vallásos útkeresés iránt [27]. A vallás sokoldalúságát mutatja, hogy annak ellenére, hogy jelentős védőfaktor lehet a serdülők problémaviselkedésével szemben [28], veszélyeket is rejt magában, amennyiben például akár függóséget okozhat bizonyos veszélyeztetett csoportokban. Jelen tanulmányban egy rövid szưrő kérdőív segítségével megkíséreltük feltárni a vallásfüggőség megjelenését serdülőkorban, emellett jellemzőinek bemutatása is szerepelt célkitúzéseink között. Ezután összefüggéseket kerestünk a vallási addikció és más addiktív viselkedések, valamint a pszichés jóllét zavarai között. Feltételeztük, hogy a vallásfüggőség megjelenik a serdülő korosztályban $(\mathrm{Hl})$, valamint összefüggésbe hozható a szerhasználat (kémiai addikció) magasabb előfordulásával és negatívabb pszichés jóllét érzésével (H2).

\section{Módszer}

\section{Minta}

A Szegedi Ifjúságkutatás 2010-es kérdőíves adatfelvételére 2010 őszi félévében került sor Szegeden, középiskolás diákok körében $(\mathrm{N}=656)$. A begyüjtött kérdőívek száma alapján 93,7\%-os válaszadási arányt állapítottunk meg (700 kérdőívból). A mintába véletlenszerú mintavétellel négy középiskola diákjai kerültek be, a következő iskolatípus szerinti megoszlással: 20,6\% gimnázium, 63,4\% szakközépiskola és 16,0\% szakiskola. A megkérdezettek életkor szerint 14 és 21 év közöttiek, átlagéletkor 16,5 év (szórás = 1,5) volt. (A mintában szerepeltek 5-6. évfolyamon tanuló diákok is.) A nemek megoszlása a következőképpen alakult: 49,2\% lány, 50,8\% fiú.

\section{Mérōeszközök}

A vallásosságot a következő változókkal mértük: vallási hovatartozás, vallási aktivitás, a vallás fontossága, illetve mértéke $[3,4,28]$. A vallási hovatartozással kapcsolatban a vallási felekezetre, illetve aktuálisan a vallási közösségbe tartozásra kérdeztünk rá. A vallási aktivitást két változó mentén mértük: „Milyen gyakran jársz templomba vagy vallási jellegü rendezvényekre?”, illetve „Milyen gyakran imádkozol, meditálsz?” A válaszkategóriák 
a következők voltak: soha, alkalmanként/ünnepekkor, havonta, hetente egyszer, hetente többször, naponta. A vallásosság mértékét szintén a korábbi kutatásokban már használt hétfokozatú skálával mértük, ahol 1 = egyáltalán nem vallásos, 7 = nagyon vallásos értéket kapott. A vallás fontosságát, szerepét az egyén életében további három item segítségével mértük: „Mennyire vagy biztos a hitedben, vallási meggyőződésedben?”, illetve „Menynyire fontos számodra a vallás?”, „Mennyire fontos a vallás a mindennapi életedben?” Mindhárom esetben négyfokozatú skála állt rendelkezésre a válaszadáskor [27]. A három kérdésből készített összevont index megbízhatóságát mérő Cronbach-alfa értéke 0,87 lett.

Barry és Nelson [27] kutatása alapján mértük fel a vallás szerepét. Arra kértük a fiatalokat, hogy értékeljék (4 fokú Likert-skálán), mennyire tartják fontosnak, hogy mások tudjanak a vallási meggyőződésükről, hitükről, amikor valaki meg akarja ismerni őket. A kérdések között szerepelt például: „Mennyire tartod fontosnak, hogy a barátaidnak hasonló legyen a vallási meggyőződése, hite?”, „Mennyire tartod fontosnak, hogy olyan lánynyal/fiúval járj, akinek hasonló a hite, vallási meggyőződése?"

A vallási addikcióra egy bármilyen viselkedéses addikcióra használható rövid szűrő kérdőívet vettünk fel [29]. A kérdőív összesen hat tételből áll (például: „A vallást arra használom, hogy a hangulatomon változtassak (például, hogy kellemesebben érezzem magam, vagy, hogy ne kelljen a problémáimmal foglalkoznom"), ahol az egyetértés fokát egy ötfokú skálán jelezték a megkérdezettek. A hat állításra adott válasz összegzése után három csoportra osztottuk a válaszadókat: 0-12 pont között aszimptomatikus, 13-23 pont között szimptomatikus és a 24 pontot vagy annál többet elérők körében beszélhetünk addikcióról [9]. A skála megbízhatóságát jellemző Cronbach-alfa értéke 0,89 lett a saját mintával.

A spirituális jóllét mérésére az úgynevezett Spiritual Well-Being Skálát alkalmaztuk [30,31]. Két alskálából áll, amelyek közül az egyik a vallási jóllétet (religious well-being), a másik pedig az egzisztenciális jóllétet (existential well-being) méri. A vallási jóllét skálán elsősorban Istennel vagy egy Magasabb Hatalommal való kapcsolat áll a kérdések középpontjában (például: „Hiszek abban, hogy Isten vagy egy Természetfeletti Hatalom szeret engem és törődik velem”). Az egzisztenciális jóllét itemei pedig az élet értelmére vonatkoztak (például: „Hiszem, hogy van igazi célja az életemnek”) és a túlvilággal való kapcsolatra. A válaszlehetőségek a következők voltak: egyáltalán nem értek egyet $=1$; nem értek egyet $=2$; is-is $=3$; egyetértek $=4$; teljesen egyetértek $=5$. Az öszszesített skálapontok mindkét esetben 5-25 értéket kaphattak. Az alskálák megbízhatósági értékét jelző Cronbach-alfa-értékek a jelen mintával a következők lettek: 0,75 (vallási jóllét) és 0,64 (egzisztenciális jóllét), valamint 0,68 (spirituális jóllét, összetett mutató).

Az egészség-magatartás esetében a szerkipróbálás és az aktuális dohányzás, alkohol- és marihuána/amfetamin fogyasztás dichotomizált formáit használtuk fel, hogy a megkérdezett kipróbálta/nem próbálta ki a felsorolt szereket, illetve hogy egyáltalán nem fogyasztott/fogyasztott, mennyiségtől függetlenül, a megelőző három hónap alatt.

A pszichés állapotra vonatkozóan először a depressziós tünetek megjelenését vizsgáltuk. Mérésére a Child Depression Inventory (CDI) magyar nyelvre adaptált, rövidített változatát alkalmaztuk [32]. A jelen mintával a skála megbízhatóságát jellemző Cronbach-alfa értéke 0,75 lett. A pszichológiai jellemzők között szerepelt még az Élettel való elégedettség globális skálája (The Satisfaction With Life Scale, SWLS) [33]. A skála megbízhatóságát mérő Cronbach-alfa értéke a saját mintával 0,83 volt. Továbbá mértük az optimizmus szintjét (Life Orientation Test, LOT) [34], amelynek Cronbach-alfaértéke: 0,70. Buss és Perry [35] agressziót mérő kérdőivét (The Aggression Questionnaire) szintén felhasználtuk, amelynek 3 alskáláját - fizikai agresszió (9 tétel), verbális agresszió ( 5 tétel) és a haragra való hajlam (7 tétel) - vontuk be az elemzésbe. Példák az egyes alskálákra: fizikai agresszivitás, például: „Van úgy, hogy nem tudom kontrollálni magam, hogy meg ne üssek valakit”; verbális agresszió, például: „Gyakran vitatkozom az emberekkel”; harag/düh, például: „Néhány barátom forrófejünek tart”. A válaszokat 1-tôl 5 -ig terjedő skálán kellett elhelyezni, ahol az 1 = egyáltalán nem értek egyet az állítással, 5 = teljesen egyetértek az állítással. A fizikai agressziót mérő alskála pontértékei 9 és 45 között változhattak, a jelen mintával kiszámított megbízhatósági értéke (Cronbach-alfa) 0,81. A verbális agresszió alskáláján szerzett pontértékek 5 és 25 között mozoghattak, megbízhatósági értéke (Cronbach-alfa) 0,70. A harag/ düh alskála értékei 7 és 35 között változhattak, megbízhatósági értéke e skálának (Cronbach-alfa) 0,77 lett.

\section{Elemzés}

Az elemzéseket az SPSS 20.0 segítségével dolgoztuk fel. A statisztikai adatfeldolgozás során gyakoriságmegoszlásokat, kereszttáblákat, t-próbákat, korreláció- és lineárisregresszió-elemzést használtunk.

\section{Eredmények}

\section{A vallási hovatartozás feltérképezése}

Felekezethez kötődést a megkérdezettek 63,3\%-a jelzett, míg aktív vallási hovatartozást 39\%. A fiúk 61,9\%-a nevezett meg felekezetet, míg a lányok 64,9\%-a. A tényleges vallási hovatartozásra, aktivitásra jellemző mutató szerint a fiúk 34,4\%-a, a lányok 43,9\%-a válaszolta, hogy jelenleg vallási közösségbe tartozik. Statisztikailag egyik esetben sem volt szignifikáns az eltérés $(p>0,05)$. A felekezethez tartozók megoszlása a felekezeti hovatartozás szerint a következó értékeket mutatta: a legtöbben római katolikusok $(71,6 \%)$, ezt követte a református 
$(8,4 \%)$, illetve a görög katolikus $(3,1 \%)$, valamint az evangélikus $(2,7 \%)$ egyház. A jelölt felekezetek között megtalálható még a Hit Gyülekezete, a Jehova tanúi, a zsidó, az iszlám és a buddhizmus is.

\section{A vallásosság mértéke és a vallás fontossága}

A hétfokozatú skálán vizsgáltuk a vallásosság mértékét. A vallásosságban nem találtunk eltérést nemek szerint (fiúk: átlag $=2,44$, szórás $=1,52$; lányok: átlag $=2,41$, szórás $=1,42, p>0,05)$. Az 1. táblázat mutatja be a vallás szerepére, fontosságára vonatkozó kérdésekre adott válaszok megoszlását. A válaszolók többsége számára nem fontos a vallás, a fiúk 72\%-ának, a lányok 71,9\%-ának. Viszont a nagyon fontos kategória választásában is a fiúk értek el magasabb arányt: $8,9 \%$ vs. 5,4\% (1. táblázat). A vallás mindennapi életben betöltött szerepe esetében ezek az arányok hasonlóan alakultak, a fiúk 75,8\%-ának, míg a lányok 75,4\%-ának nem fontos a vallás a mindennapi életben. Emellett a nagyon fontos kategóriát a fiúk 7,3\%-a és a lányok 4,8\%-a választotta.

\section{Vallási aktivitás, vallásgyakorlás}

Szintén az 1. táblázat mutatja be a megkérdezett fiatalok vallási aktivitását nemek szerinti bontásban. A megkérdezettek 56,5\%-a soha nem jár templomba, a fiúknál ez az

1. táblázat |A vallás szerepének megítélése és vallási aktivitás a mintában (százalékban)

\begin{tabular}{|c|c|c|c|}
\hline & Fiúk & Lányok & Szignifikancia \\
\hline \multicolumn{4}{|l|}{$\begin{array}{l}\text { Mennyire fontos számodra } \\
\text { a vallás? }\end{array}$} \\
\hline Nagyon & 8,9 & 5,4 & \\
\hline Eléggé & 19,1 & 22,7 & \\
\hline Alig & 37,3 & 42,8 & \\
\hline Egyáltalán nem & 34,7 & 29,1 & $\mathrm{p}=0,05$ \\
\hline \multicolumn{4}{|c|}{$\begin{array}{l}\text { Mennyire fontos számodra } \\
\text { a vallás a mindennapi életben? }\end{array}$} \\
\hline Nagyon & 7,3 & 4,8 & \\
\hline Eléggé & 16,9 & 19,8 & \\
\hline Alig & 37,3 & 41,9 & \\
\hline Egyáltalán nem & 38,5 & 33,5 & $\mathrm{p}>0,05$ \\
\hline \multicolumn{4}{|l|}{$\begin{array}{l}\text { Mennyire vagy biztos } \\
\text { a bitedben? }\end{array}$} \\
\hline Nagyon & 14,3 & 9,9 & \\
\hline Eléggé & 30,9 & 29,5 & \\
\hline Alig & 27,7 & 30,5 & \\
\hline Egyáltalán nem & 27,1 & 30,1 & $\mathrm{p}>0,05$ \\
\hline \multicolumn{4}{|l|}{ Vallásos aktivitás } \\
\hline Nem jár gyülekezetbe & 61,2 & 51,9 & \\
\hline Csak ünnepekkor & 35,5 & 42,0 & \\
\hline Változó rendszerességgel & 3,3 & 6,1 & $\mathrm{p}<0,05$ \\
\hline \multicolumn{4}{|l|}{ Imádkozás } \\
\hline Nem szokott & 93,1 & 88,3 & \\
\hline Szokott & 6,9 & 11,7 & $\mathrm{p}=0,05$ \\
\hline
\end{tabular}

$\chi^{2}$-próba. arány 61,2\%, a lányoknál 51,9\%. 39,0\% csak ünnepek alkalmával vesz részt vallási jellegú eseményeken (fiúk: $35,5 \%$, lányok: $42,0 \%)$. A rendszeres templomba járás a fiúk 3,3\%-ára, míg a lányok 6,1\%-ára jellemző. Az imádkozás gyakorisága hasonlóképpen alakult: összesen 48,8\% soha (fiúk: $52,3 \%$, lányok: $45,8 \%$ ), és 9,5\% imádkozik rendszeresen (fiúk: 7\%, lányok: $11,7 \%$ ). A két változó közötti korreláció magas: $\mathrm{r}=0,726 ; \mathrm{p}<0,001$. A templomba járás gyakoriságában figyelhető meg nemenkénti eltérés a lányok javára $(\mathrm{p}<0,05)$, az imádkozás gyakoriságában viszont nem tapasztalható szignifikáns eltérés $(\mathrm{p}>0,05)$.

\section{A vallásiaddikció-skála bemutatása}

A vallásfüggőséget mérő skála hat állítást tartalmaz. Az elsó állítás: „A vallásgyakorlás a legfontosabb dolog az életemben", ez a kiemelkedőség (salience) dimenziója. Itt mérhetővé válik, hogy a vallás mennyire dominál az egyén életében, gondolataiban, érzelmeiben és viselkedésében. Ezzel az állítással mindössze a diákok 5,7\%-a értett egyet (2,4\% teljes mértékben, 3,3\% inkább egyetért). Az egyetértés elutasítása sokkal jellemzőbb volt, $49,2 \%$ egyáltalán nem a vallást tartja a legfontosabb dolognak az életében. A második állítás a konfliktus (conflict) dimenziója, amely az interperszonális konfliktusokra fokuszál: „Konfliktusok adódnak köztem és a családom és/vagy partnerem között amiatt, hogy mennyit foglalkozom a vallással, vallásgyakorlással.” A minta 3,2\%-a értett egyet ezzel az állítással, míg 70,4\%-uk teljes mértékben elutasította, hogy ez igaz lenne. A harmadik állítás a hangulatmódosításra (mood-modification) vonatkozott: „A vallást arra használom, hogy a hangulatomon változtassak (például, hogy kellemesebben érezzem magam, vagy, hogy ne kelljen a problémáimmal foglalkoznom)." A minta 5,3\%-ára igaz, hogy használja a vallást, mint hangulatmódosító eszközt. Ezután a tolerancia (tolerance) dimenziójára koncentrál a skála: „Az elmúlt időszak során növeltem a napi imák/meditációk mennyiségét." Ez az állítás a vallási aktivitás növekvő mértékét hivatott felmérni. A diákok 4,9\%-ánál mutatható ki, hogy növelték az imamennyiséget, ugyanakkor 67,1\%-ukra ez egyáltalán nem igaz. A megvonásos tünetek dimenzióját (withdrawal symptoms) a következő kérdés mentén mértük: „Ha ki kell hagynom egy istentiszteletet, rosszkedvű és ideges leszek.” A megvonás csupán a minta 2,2\%-ára jellemző. A hatodik, egyben utolsó állítás a visszaesés (relapse) dimenziója: „Ha lecsökkentem a szokásos imá$\mathrm{im} /$ meditációim mennyiségét, akkor, amikor újra elkezdem, addig folytatom, amíg az eredeti mennyiséget el nem érem." Fontos kiemelni, hogy ez az állítás mutatta a legkisebb veszélyeztetettséget, a diákok mindössze 1,5\%-a érintett a kérdésben.

A hat állításra adott válasz összegzése után, Griffiths [9] besorolása alapján, három csoportot különítettünk el: a 24 pontot vagy annál többet elérôk körében beszélhetünk vallási addikcióról - a minta $0,8 \%$-a jellemezhető 


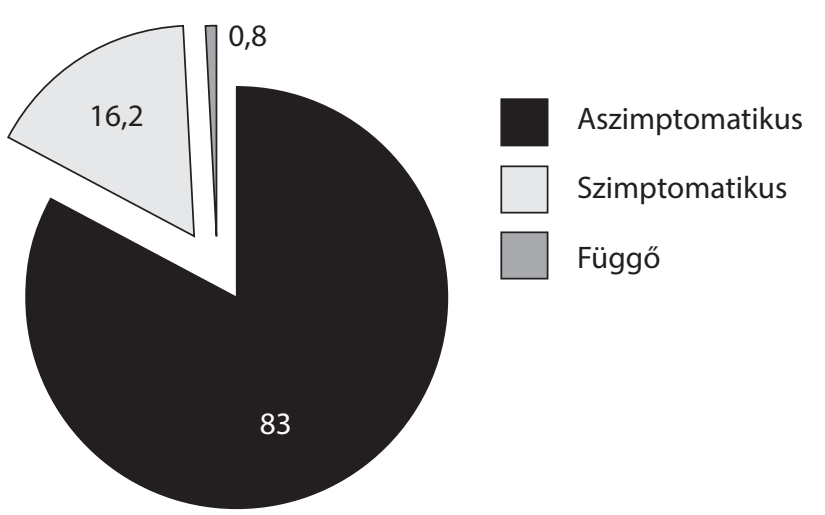

1. ábra | Vallási addikció szerinti csoportok százalékos megoszlása

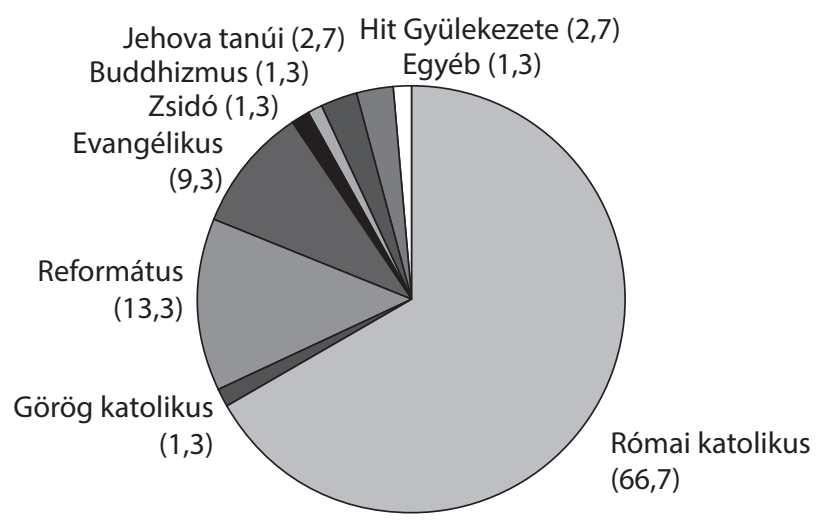

2. ábra |Vallási megoszlás a rizikócsoportban

vallásfüggőként. Emellett a 13-23 pontot elérőket szimptomatikus, tüneteket mutató csoportba soroltuk a minta 16,2\%-a veszélyeztetett az addikció szempontjából, így a két kategóriát összevonva a teljes minta 17\%-át $(\mathrm{N}=107)$ jellemezhetjük rizikócsoportként (a teljes minta elemszáma $\mathrm{N}=630$ ). A harmadik csoport a 0-12 pontot elérók csoportja, az aszimptomatikus, azaz tünetmentes csoport, $83 \%$-os arányt mutatott (1. ábra) $(\mathrm{N}=523)$ *

Megvizsgáltuk, hogy a vallásfüggők vajon milyen felekezethez tartoznak, formálisan tartoznak-e valláshoz, felekezethez. A válaszok alapján megállapíthatjuk, hogy a rizikócsoportba tartozók többsége $(60,8 \%)$ magát valláshoz, felekezethez tartozónak vallja. ** A vallásfüggőség szempontjából a veszélyeztetett csoportban nagyarányú a római katolikus $(66,7 \%)$, a református $(13,3 \%)$, az evangélikus $(9,3)$, valamint a jehovisták és a Hit Gyülekezete hívei (2. ábra).

*A fiúk szignifikánsan felülreprezentáltak a kockázati csoportban: 21,7\% vs. lányok $12,3 \%(\mathrm{p}<0,01)$.

${ }^{* *}$ Itt fontos kiemelni, hogy az aszimptomatikus csoportban ez az arány csupán $35,6 \%(\mathrm{p}<0,001)$.

\section{A vallásfüggőség szociodemográfiai háttere}

A szociodemográfiai jellemzőket górcső alá véve szintén érdekes eredményekhez jutottunk. A nemi különbségek vizsgálatakor egy meglepő eredményre lettünk figyelmesek. Habár a lányok vallási aktivitása általánosságban véve magasabb, a fiúknál a vallás szerepe fontosabb, ami esetenként függőséghez is vezethet. A vallásfüggőség skáláján elért pontszámok a következőképpen alakultak: $\mathrm{M}($ fiú $)=9,6, \mathrm{M}$ (lány) = 8,7; p<0,01. A vallásfüggők/ vallásfüggőség szempontjából veszélyeztetettek almintájában a fiúk aránya 63,6\%-ot mutatott, szemben a nem vallásfüggő́k csoportjával, ahol a nemek aránya kiegyensúlyozottnak mondható $(46,9 \%$ a fiúk aránya, $\mathrm{p}<0,01)$. Életkor tekintetében, bár eredményeink nem mutattak szignifikáns eltéréseket $(p>0,05)$, a vallásfüggő́k valamivel fiatalabbnak bizonyultak társaiknál. A társadalmi ranglétrán elfoglalt hely nem mutatott domináns eltéréseket a megoszlásban, habár a vallásfüggók inkább a közép- és felső középosztályban helyezték el családjukat $(\mathrm{p}<0,05)$. Tanulmányi átlag tekintetében különbség mutatkozott, a vallásfüggők átlaga, igen csekély mértékben ugyan, de magasabb, mint a nem vallásfüggók csoportjában $(\mathrm{p}<0,05)$.

\section{Vallási változók és a vallásfüggőség közötti összefüggések}

Az elemzés következő fázisában kitűzött célként szerepelt, hogy feltárjuk, vajon milyen vallási változók állhatnak a vallási addikció, vallásfüggőség hátterében. Első lépésben korrelációelemzést végeztünk, majd lineárisregresszió-elemzés segítségével tártuk fel, hogy a vallási változók hogyan hatnak a vallásfüggőségre. A korrelációelemzés kimutatta, hogy annak hite, hogy Isten figyel és irányítja az életünket, valamint a vallás általános és a mindennapi életben való fontossága, továbbá a vallásosság

2. táblázat |A vallásfüggőség összefüggései a vallási változókkal korrelációelemzés alapján

\begin{tabular}{lc}
\hline & Vallásfüggőség \\
\hline Mennyire vallásos? & $0,546^{*}$ \\
Mennyire biztos a hitében? & $0,361^{*}$ \\
Mennyire fontos a vallás? & $0,530^{*}$ \\
Mennyire fontos a vallás a mindennapokban? & $0,546^{*}$ \\
Tartozik-e egyházhoz? & $0,211^{*}$ \\
Milyen gyakran jár templomba? & $0,459^{*}$ \\
Milyen gyakran imádkozik? & $0,497 *$ \\
Barátoknak hasonló legyen a hite & $0,497 *$ \\
Partnernek hasonló legyen a hite & $0,433^{*}$ \\
Hasonló vallásúval házasodjon & $0,433^{*}$ \\
Isten figyel és irányítja életünket & $0,560 *$ \\
\hline
\end{tabular}

${ }^{*} \mathrm{p}<0,001$; korrelációs együtthatók. 
3. táblázat |A vallásfüggőség háttérváltozói többváltozós regresszióelemzés alapján

\begin{tabular}{lrc}
\hline & $\beta$ & $\begin{array}{c}\text { Szignifi- } \\
\text { kancia }\end{array}$ \\
\hline Mennyire vallásos? & 0,152 & $p<0,05$ \\
Mennyire biztos a hitében? & 0,078 & $\mathrm{p}>0,05$ \\
Mennyire fontos a vallás? & 0,104 & $\mathrm{p}>0,05$ \\
Mennyire fontos a vallás a mindennapokban? & $-0,156$ & $p<0,05$ \\
Tartozik-e egyházhoz? & 0,031 & $\mathrm{p}>0,05$ \\
Milyen gyakran jár templomba? & 0,170 & $p<0,01$ \\
Milyen gyakran imádkozik? & $-0,053$ & $\mathrm{p}>0,05$ \\
Barátoknak hasonló legyen a hite & $-0,143$ & $p<0,05$ \\
Partnernek hasonló legyen a hite & $-0,015$ & $\mathrm{p}>0,05$ \\
Hasonló vallásúval házasodjon & 0,004 & $\mathrm{p}>0,05$ \\
Isten figyel és irányítja életünket & 0,064 & $\mathrm{p}>0,05$ \\
\hline R-négyzet & 0,453 & $p<0,001$ \\
Konstans & 14,72 & $p<0,001$ \\
\hline
\end{tabular}

Regressziós együtthatók.

mértéke mutatta a legerősebb kapcsolatot a vallásfüggőséggel (2. táblázat).

Ezután regresszióanalízist futtattunk le, ami megerősítette a korrelációelemzés eredményeit, és a ß statisztikákból az egyes változók befolyásolási sorrendjére is következtethettünk (3. táblázat).

A regresszióanalízis azt mutatta, hogy a vallásosság mértéke, a vallás mindennapi életben betöltött szerepe, a vallási aktivitás és a vallási érték homogámiája hatnak leginkább a vallási addikcióra. Tehát, ha valaki minél gyakrabban jár templomba, minél fontosabbnak tartja a vallást a mindennapjaiban, minél vallásosabbnak véli önmagát és minél fontosabbnak tartja, hogy az őt körül vevő baráti körnek hasonló legyen a hitbéli meggyőződése, annál veszélyeztetettebb a vallásfüggőség kialakulása terén.

\section{Az úgynevezett vallásfüggö kockázati csoport sajátosságai}

A további elemzésekhez, a vallásfüggók kis elemszáma miatt, a függóket és a szimptomatikus csoportba tartozókat egy kategóriába vettük, amely a „vallásfüggő rizikócsoport” elnevezést kapta. Ezt követően statisztikai elemzéseket végeztünk annak érdekében, hogy kiderüljön, a vallásfüggók rizikócsoportjában $(\mathrm{N}=107)$ és az aszimptomatikusok csoportjában $(\mathrm{N}=523)$ mely változók mentén vannak lényeges eltérések. A kereszttáblaelemzések azt igazolták, hogy míg a vallásfüggő rizikócsoport 22,7\%-a gyakran jár templomba, addig az aszimptomatikus csoport körében ez az arány mindössze $0,8 \%(\mathrm{p}<0,001)$. Az imádkozás gyakoriságában szintén szignifikáns a különbség a két csoportban, míg a vallás- függők/vallásfüggőség szempontjából veszélyeztetettek 33,0\%-a gyakran imádkozik, addig a másik csoportban csupán 3,6\%-uk tesz így $(\mathrm{p}<0,001)$. A vallás fontosságánál és a mindennapi életben betöltött szerepénél ugyanezt a tendenciát figyelhetjük meg. A vallásfüggő rizikócsoportba tartozók szignifikánsan fontosabbnak értékelték a vallást, és biztosabbak a hitükben $(\mathrm{p}<0,001)$. Ki kell még emelnünk azt is, hogy a vallásfüggők/vallásfüggőség szempontjából veszélyeztetettek inkább fontosnak tartják, hogy a baráti körük (12,2\% vs. 1,7\%), partnerük (11,2\% vs. $2,5 \%)$, valamint jövendóbelijülk $(20,6 \%$ vs. $4,8 \%)$ hasonló vallási nézetekkel rendelkezzen, mint ók maguk; és inkább hiszik, hogy Isten figyel és irányítja életüket ( $17,8 \%$ vs. $2,3 \% ; \mathrm{p}<0,001)$. Mindezek megerősítik a korreláció- és regresszióelemzés eredményeit a vallási változók csoportképző szerepérôl a veszélyeztetettség szempontjából.

\section{Vallásfüggőség és szerhasználat}

Először kétmintás t-próbák segítségével kerestünk összefüggést a vallásfüggőség és a szerkipróbálás, szerhasználat változói között (4. táblázat), majd pedig a már említett két csoportban (vallásfüggő rizikócsoport és

4. táblázat $\mid$ A vallásfüggőség mértéke a szerkipróbálás (életprevalencia) és a szerhasználat (havi prevalencia) függvényében

\begin{tabular}{|c|c|}
\hline & $\begin{array}{c}\text { Vallásfüggoóség-skála } \\
\text { (átlag, szórás) }\end{array}$ \\
\hline \multicolumn{2}{|c|}{ Dohányzás kipróbálása } \\
\hline Nem & $9,59(3,91)$ \\
\hline Igen & $8,98(4,07)$ \\
\hline \multicolumn{2}{|c|}{ Dohányzás jelenleg } \\
\hline Nem & $9,01(3,94)$ \\
\hline Igen & $8,96(4,08)$ \\
\hline \multicolumn{2}{|c|}{ Alkohol kipróbálása ${ }^{\#}$} \\
\hline Nem & $10,50(4,84)$ \\
\hline Igen & $9,03(3,95)$ \\
\hline \multicolumn{2}{|c|}{ Alkoholfogyasztás jelenleg* } \\
\hline Nem & $9,97(4,37)$ \\
\hline Igen & $8,96(3,94)$ \\
\hline \multicolumn{2}{|c|}{ Nagyivás* } \\
\hline Nem & $9,55(3,86)$ \\
\hline Igen & $8,90(4,11)$ \\
\hline \multicolumn{2}{|c|}{ Marihuána kipróbálása } \\
\hline Nem & $9,27(3,92)$ \\
\hline Igen & $8,69(4,37)$ \\
\hline \multicolumn{2}{|c|}{ Marihuánafogyasztás } \\
\hline Nem & $9,19(3,95)$ \\
\hline Igen & $8,81(4,51)$ \\
\hline \multicolumn{2}{|c|}{ Amfetamin kipróbálása* } \\
\hline Nem & $9,07(3,87)$ \\
\hline Igen & $10,62(4,48)$ \\
\hline \multicolumn{2}{|c|}{ Amfetaminhasználat } \\
\hline Nem & $9,10(3,95)$ \\
\hline Igen & $10,29(6,43)$ \\
\hline
\end{tabular}

* $\mathrm{p}<0,05 ;{ }^{*} \mathrm{p}=0,06 ;$ kétmintás t-próba. 
aszimptomatikus csoport) hasonlítottuk össze a szerfogyasztási gyakoriságokat (5. táblázat).

Az átlagokat érintő elemzések (4. táblázat) alapján elmondhatjuk, hogy nem volt eltérés a dohányzók és a marihuánafogyasztók vallásfüggőség szintjében $(p>0,05)$ sem az élet-, sem pedig a havi prevalencia szintjén. Az alkoholt fogyasztók kevésbé hajlamosak vallásfüggőségre $(\mathrm{p}<0,05)$. Ugyanakkor az amfetamint kipróbálók szignifikánsan nagyobb pontszámot értek el a vallásfüggőségskálán $(\mathrm{p}<0,05)$.

Kereszttáblákkal megvizsgálva szintén az amfetamin kipróbálásánál találtunk szignifikáns különbséget a vallásfüggők/vallásfüggőség szempontjából veszélyeztetettek és nem vallásfüggők csoportjai között (5. táblázat).

5. táblázat | Különbségek a vallásfüggő rizikócsoport és a nem vallásfüggők csoportja között a szerkipróbálásban és szerhasználatban

\begin{tabular}{lccc}
\hline & $\begin{array}{c}\text { Vallásfüggő } \\
\text { rizikócsoport }\end{array}$ & $\begin{array}{c}\text { Nem } \\
\text { vallásfüggók } \\
\text { (aszimpto- } \\
\text { matikusok) }\end{array}$ & Szignifikancia \\
\hline Dohányzás kipróbálása & $68,2 \%$ & $74,1 \%$ & $\mathrm{p}>0,05$ \\
Dohányzás & $64,2 \%$ & $59,4 \%$ & $\mathrm{p}>0,05$ \\
Alkohol kipróbálása & $89,7 \%$ & $94,1 \%$ & $\mathrm{p}>0,05$ \\
Alkoholfogyasztás & $78,5 \%$ & $84,0 \%$ & $\mathrm{p}>0,05$ \\
Nagyivás & $59,4 \%$ & $63,8 \%$ & $\mathrm{p}>0,05$ \\
Marihuána kipróbálása & $17,8 \%$ & $24,1 \%$ & $\mathrm{p}>0,05$ \\
Marihuánafogyasztás & $12,1 \%$ & $13,7 \%$ & $\mathrm{p}>0,05$ \\
Amfetaminkipróbálás & $7,5 \%$ & $4,0 \%$ & $p<0,05$ \\
Amfetaminhasználat & $3,7 \%$ & $2,5 \%$ & $\mathrm{p}>0,05$ \\
\hline
\end{tabular}

$\chi^{2}$-próba.

\section{Vallásfüggöség és pszichés jóllét}

Kétmintás t-próbával kerestük a különbségeket a pszichés változók között a vallásfüggők/vallásfüggőség szempontjából veszélyeztetettek és az aszimptomatikus csoportok között (6. táblázat).

Az agresszió skáláin alacsonyabb értékeket jeleztek a vallásfüggő rizikócsoportba tartozók, különösen igaz ez a verbális agresszió szintjén $(\mathrm{p}<0,001)$. A depressziós tünetek, az optimizmus és az élettel való elégedettség mértékében nem volt jelentős eltérés a két csoport között ( $p>0,05)$. Ki kell még emelni, hogy a spirituális jóllét egyik alskálájával kapcsolatban szignifikánsan magasabb vallási jóllétről számoltak be a vallásfüggő rizikócsoportba tartozók, mint társaik.

\section{Megbeszélés}

A vallásfüggőség, vallási addikció egy új jelenség a viselkedési addikciók között [14, 15, 16, 17, 20, 21], amelynek a részletes empirikus kutatása még hiányzik a nem-
6. táblázat $\mid$ Különbségek a vallásfüggő rizikócsoport és a nem vallásfüggők csoportja között a pszichés háttérváltozókban

\begin{tabular}{lcc}
\hline & $\begin{array}{c}\text { Vallásfüggő } \\
\text { rizikócsoport } \\
\text { (átlag, szórás) }\end{array}$ & $\begin{array}{c}\text { Nem vallásfüggők } \\
\text { (aszimptomatikusok) } \\
\text { (átlag, szórás) }\end{array}$ \\
\hline Verbális agresszió* * $^{\text {Fizikai agresszió* }}$ & $13,97(3,4)$ & $15,32(3,5)$ \\
Harag/düh érzet & $22,41(6,5)$ & $23,80(7,0)$ \\
Depressziós tünetek & $17,41(4,8)$ & $17,98(5,3)$ \\
Élettel való elégedettség & $6,98(7,7)$ & $7,08(7,8)$ \\
Optimizmus & $22,30(6,5)$ & $21,99(6,1)$ \\
Vallási jóllét* * & $27,07(5,0)$ & $27,38(5,0)$ \\
Egzisztenciális jóllét & $17,05(3,8)$ & $11,66(3,7)$ \\
\hline
\end{tabular}

${ }^{*} \mathrm{p}<0,05 ;{ }^{*} \mathrm{p}<0,001 ;$ kétmintás t-próba.

zetközi és magyar kutatási palettáról. Jelen kutatás céljául tüztük ki a jelenség megismerését, a vallásfüggőség megjelenésének kimutatását a serdülő korosztályban. Ezzel összefüggésben arra koncentráltunk, hogy mely jellemzők mentén írható le ez az új viselkedési addikció.

Az eredményeink azt mutatják, hogy a vallásosság alacsony szinten van a mai fiatalok körében. Ennek ellenére mégis azt tapasztalhattuk, hogy a vallásfüggőség, ugyan kis arányban (0,8\%-ban), de előfordult. Ezzel igazoltuk az ezzel kapcsolatos hipotézisünket $(\mathrm{Hl})$. Azért is fontos kiemelni e jelenség létjogosultságát, mert az úgynevezett vallásfüggő rizikócsoportba tartozott a minta 16,2\%-a. A bizonytalan serdülők sérülékenyek, ezért számukra kockázatossá válhat a vallási tartalmak mindenekfeletti betartása és az életvezetés leszúkítése a vallási jellegű tevékenységekre, vallási jellegú aktivitásra, ami egyfajta biztonságot nyújthat számukra [26, 27].

A kutatásunkban először magát a mérőeszközt kívántuk bemutatni, a hat állításból álló szűrő kérdőívet és az egyes itemekre adott válaszok százalékos megoszlását. A hat állítás hat dimenziót ölel fel, mégpedig a kiemelkedőség, a konfliktus, a hangulatváltoztatás, a tolerancia, a megvonásos tünetek és a visszaesés dimenzióit [9, 29]. Az állításoknál 1,5 és 5,7\% körül mozgott az egyetértés aránya, tehát azok aránya, akik veszélyeztetettek a függés szempontjából. Legnagyobb egyetértést a kiemelkedőségnél tapasztaltunk, legkisebbet pedig a visszaesésnél.

A vallásfüggőkre jellemző, hogy szignifikánsan vallásosabbnak tartják magukat, többször járnak templomba, és többször imádkoznak, illetve a vallás szerepét fontosabbnak ítélik saját életükben. Szoros kapcsolatot találtunk a vallásfüggőség-skála és az egyes vallási változók között. Lineárisregresszió-analízissel megvizsgáltuk, hogy a vallásosság mely komponensei állhatnak a függőség hátterében. A vallásfüggőség prediktorai: a vallásosság mértéke, a templomba járás gyakorisága és a vallás mindennapi életben elfoglalt helye, valamint a barátok vallásossága. A szociodemográfiai háttér vizsgálatában több érdekességre bukkantunk. Habár a lányok vallási 
aktivitása magasabb, a fiúknál a vallás szerepe fontosabb, ami esetenként függőséghez is vezethet. Az is nyilvánvalóvá vált, hogy a társadalmi ranglétrán inkább a közép- és felső középosztályból kerülnek ki a függők (vö. a vallásosság hazai társadalmi mintázatával) [36].

A szerfogyasztás esetében is találtunk különbségeket a vallásfüggő és az aszimptomatikus csoportban. Bár az alkoholt fogyasztók vallásfüggőségre való hajlama inkább kisebb, az amfetamin kipróbálása egyértelmúen a vallásfüggő rizikócsoportban nagyobb mértékü. Ezt úgy is értelmezhetjük, hogy míg az alkoholfogyasztásnál inkább a védőfaktor jellege realizálódik, a „keményebb” droghoz fordulás összefügghet a vallási addikcióval. A drogfogyasztás és a vallásgyakorlás közötti összefüggésről korábban is beszámoltak, utalva arra, hogy mindkettó esetében szó lehet egyfajta tudatmódosítás iránti igényrôl vagy útkeresésről [37]. A pszichés jóllét kapcsán az elemzésünk azt mutatta, hogy alacsonyabb az agresszió szintje, továbbá magasabb a vallási jóllét a vallásfüggők és vallásfüggésre hajlamos fiatalok körében. Második hipotézisünk (H2) tehát csak részben igazolódott be, amennyiben a vallásfüggôség akár veszélyes is lehet a serdülő pszichoszociális egészségére nézve, amit leginkább az amfetaminfogyasztás támasztott alá. Mivel az általunk alkalmazott skála nem tett különbséget a vallásfüggőség három stádiuma között, feltételezhető, hogy itt még egyfajta kiegyensúlyozottság dominálhat, ami emelheti a fiatalok élettel való elégedettségét, hiszen a vallás mint eszmerendszer válaszokat adhat az élet értelmére, és egyfajta vigaszt is nyújthat [5]. A drogfogyasztással való kapcsolat mélyebb megértése további vizsgálatokat igényel.

\section{Következtetések}

A különböző függőségek ártalmainak csökkentésére prevenciós és intervenciós technikák kidolgozására van szükség a hosszú távú egészségmegőrzés szempontjából. A fiatal generáció a sérülékeny tinédzserkorban találkozik az egészségkárosító magatartásokkal, a szerkipróbálással és a szerfogyasztással [3]. Az identitásválságukat megélő fiatalok pszichés állapotára jellemző lehet a szorongásos és depressziós tünetek megjelenése. Eredményeink közül elsősorban az amfetaminfogyasztással való összefüggést emelnénk ki, ami utalhat arra, hogy a drogfogyasztó fiatalok hajlamosabbak vallási függőségre. Ennek alapja a kémiai és viselkedési addikciók közös neurobiológiai háttértényezője, a Hollander által jutalomhiányos tünetegyüttes jelenléte lehet [38]. Ez a biológiai sérülékenység tehát kiemelten veszélyeztetetté teheti a fiatalokat mind a kémiai, mind pedig a viselkedési addikciók iránt.

A fiatalok egészségprevenciós és egészségpromóciós programjaiba célszerú lenne beültetni a társadalmi-kulturális védőfaktorokat, felismerni jelentőségüket. A vallásosság kiváltképpen bonyolult jelenség, ezért mindenképpen fontos azt feltárni, hogy a vallásosság mely szintjei funkcionálnak egészségvédő és melyek egészségkárosító módon. Jelen kutatás arra hivatott rámutatni, hogy az éremnek két oldala van. A vallás és vallásosság számos esetben pozitívumokat hordoz az egyéni életútra nézve, azonban a túlzott mértékű vallásosság, a patologikus vallásosság már inkább veszélybe sodorja az egyént. Következésképpen egy megfelelő szintű, optimális vallásosság/spiritualitás megtalálása lehet a cél a serdülők szocializációs folyamatában.

Anyagi támogatás: A közlemény megírása anyagi támogatásban nem részesült, a kapcsolódó kutatómunkát az ETT 012-08/2009 projekt támogatta.

Szerzői munkamegosztás: K. E.: Az elemzés hipotéziseinek kidolgozása, elemzés, a tanulmány első változatának megszövegezése. K. E., P. B.: A kutatás tervezése és kivitelezése, a tanulmány végső formába öntése. A közlemény végleges változatát mindkét szerző elolvasta és jóváhagyta.

Érdekeltségek: A szerzőknek nincsenek érdekeltségeik.

\section{Irodalom}

[1] Kopp, M., Székely, A., Skrabski, Á.: Religion and health in a changing society. [Vallásosság és egészség az átalakuló társadalomban.] Mentálhig. Pszichoszom., 2004, 5(2), 103-125. [Hungarian]

[2] Kézdy, A., Martos, T., Urbán, Sz., et al.: The relationship between religious attitudes, coping strategies and mental health in adolescence and young adulthood. [A vallásos attitûdök, a megküzdési módok és a lelki egészség összefüggései serdülő- és fiatal felnőttkorban.] Mentálhig. Pszichoszom., 2010, 11(1), 1-16. [Hungarian]

[3] Kovács, E., Pikó, B., Fitzpatrick, K. M.: Religiosity as a protective factor against substance use among Hungarian high school students. Subst. Use Misuse, 2011, 46(10), 1346-1357.

[4] Pikó, B., Kovács, E.: Is religiosity a protective factor? Social epidemiological study of adolescent psychological health. [Vallásosság mint védőfaktor? Serdülők pszichikai egészségének szociális epidemiológiai vizsgálata.] Orv. Hetil., 2009, 150(41), 1903-1908. [Hungarian]

[5] Koenig, H.: Religion, spirituality, and health: The research and clinical implications. ISRN Psychiatry, 2012, 2012, 278730.

[6] Rácz, J.: Chemical and behavioural addictions. In: Buda, B., Kopp, M. (eds.): Behavioural Sciences.) [Kémiai és viselkedéses addikciók. In: Buda, B., Kopp, M. (szerk.): Magatartástudományok.] Medicina Könyvkiadó, Budapest, 2001. [Hungarian]

[7] Kun, B., Demetrovics, Zs. (eds.): Fundamentals of addictology, IV. [Az addiktológia alapjai IV.] ELTE Eötvös Kiadó, Budapest, 2010. [Hungarian]

[8] Dell'Osso, B., Altamura, A. C., Allen, A., et al.: Epidemiologic and clinical updates on impulse control disorders: a critical review. Eur. Arch. Psychiatry Clin. Neurosci., 2006, 256(8), 464475 .

[9] Griffiths, M.: Behavioural addiction: an issue for everybody? Emp. Couns. Today, 1996, 8(3), 19-25.

[10] Adamovova, L.: Implicit theories of religious fundamentalism among Slovak young adults. Stud. Psychol., 2005, 47(3), 235246. 
[11] Iannaccone, L. R., Berman, E.: Religious extremism: The good, the bad, and the deadly. Public Choice, 2006, 128, 109-129.

[12] Knaner, S.: Recovering from sexual abuse, addictions, and compulsive behaviors. "Numb" survivors. Haworth Social Work Practice Press, Routledge, 2002.

[13] Painter, B.: The new atheism: Denying God and history. Convers. Rel. Theol., 2008, 6(1), 89-99.

[14] Kun, B., Demetrovics, Zs.: Religious addiction. In: Kun, B., Demetrovics, Zs. (eds.): Fundamentals of addictology, IV. [Vallásfüggóség. In: Az addiktológia alapjai IV.] ELTE Eötvös Kiadó, Budapest, 2010. [Hungarian]

[15] Blue, K.: Healing spiritual abuse. Intervarsity Press, Illinois, 1993.

[16] Vanderheyden, P. A.: Religious addiction: the subtle destruction of the soul. Pastoral Psychology, 1999, 47(4), 293-302.

[17] Sussman, S., Reynaud, M., Aubin, H. J., et al.: Drug addiction, love, and the higher power. Eval. Health Prof., 2011, 34(3), 362-370.

[18] Egorov, A. Y.: New classification and psychopathology of nonchemical addictions. 1st International Conference on Behavioral Addictions. J. Behav. Addict., 2013, 2(Suppl. 1), 14.

[19] Kovács, E., Pikó, B. F.: Religious addiction: The new behavioral addiction in adolescents. 1st International Conference on Behavioral Addictions. J. Behav. Addict., 2013, 2(Suppl. 1), 19-20.

[20] Booth, L.: When God becomes a drug: Breaking the chains of religious addiction and abuse. Jeremy P. Tarcher/Putnam, New York, 1991.

[21] Booth, L.: When God becomes a drug: Understanding religious addiction and religious abuse. SCP Limited, California, 1998.

[22] Johnson, D., Van Vonderen, J.: The subtle power of spiritual abuse. Bethany House Publishers, Minneapolis, 1991.

[23] Taylor, C. Z.: Religious addiction: Obsession with spirituality. Pastoral Psychology, 2002, 50(4), 291-315.

[24] Slobodzien, J.: Hawaii and Christian religious addiction. A survey of attitudes toward healthy spirituality and religious addiction within christianity. Dissertation, USA, Hawaii, 2004.

[25] Porterfield, K.: Blind faith. CompCare Publishers, Minneapolis, 1993.

[26] Paloutzian, R. F., Park, C. L. (eds.): Handbook of the Psychology of Religion and Spirituality (2nd ed.) The Guilford Press, New York, 2013.
[27] McNamara Barry, C., Nelson, L. J.: The role of religion in the transition to adulthood for young emerging adults. J. Youth Adolesc., 2005, 34(3), 245-255.

[28] Pikó, B. F., Fitzpatrick, K. M.: Substance use, religiosity, and other protective factors among Hungarian adolescents. Addict. Behav., 2004, 29(6), 1095-1107.

[29] Terry, A., Szabó, A., Griffiths, M.: The exercise addiction inventory: A new brief screening tool. Addict. Res. Theory, 2004, 12(5), 489-499.

[30] Buford, R., Paloutzian, R., Ellison, C.: Norms for the Spiritual Well-Being Scale. J. Psychol. Theol., 1991, 19, 56-70.

[31] Boivin, M. J., Kirby, A. L., Underwood, L. K., et al.: Spiritual Well-Being Scale. In: Hill, P., Hood, R. (eds.): Measures of Religiosity. Religious Education Press, Birmingham, 1999.

[32] Kovacs, M.: Children's Depression Inventory. Multi-Health Systems, Toronto, 1992.

[33] Diener, E., Emmons, R. A., Larsen, R. J., et al.: The satisfaction with life scale. J. Pers. Assess., 1985, 49(1), 71-75.

[34] Scheier, M. F., Carver, C. S.: Optimism, coping, and health: assessment and implications of generalized outcome expectancies. Health Psychol., 1985, 4(3), 219-247.

[35] Buss, A. H., Perry, M.: The aggression questionnaire. J. Pers. Soc. Psychol., 1992, 63(3), 452-459.

[36] Székely, A.: Changes in religiosity in Hungary between 1995 and 2006. Relationship between religiosity and the number of children. Religiosity and mental health. In: Kopp, M. (ed.): Hungarian mental health 2008. [A vallásosság alakulása Magyarországon 1995-2006 között. A vallásosság összefüggései a gyermekszámmal. Vallásosság és lelki-egészségi állapot. In: Kopp, M. (szerk.): Magyar lelkiállapot 2008. Esélyerôsítés és életminőség a mai magyar társadalomban.] Semmelweis Kiadó, Budapest, 2008. [Hungarian]

[37] Bácskai, E., Gerevich, J.: Youth and drog use. [Ifjúság és drogfogyasztás.] Animula Kiadó, Budapest, 1997. [Hungarian]

[38] Hollander, E.: Obsessive-compulsive spectrum disorders: an overview. Psychiatric Annals, 1993, 23(7), 355-358.

(Pikó Bettina dr., Szeged, Szentháromság u. 5., 6722 e-mail: pikobettina@gmail.com) 